\title{
Alkyl chain functionalised, cyclometalated platinum(II) complexes: syntheses, luminescence properties and X-ray crystal structure
}

Juliette A. Lowe, ${ }^{\mathrm{a}}$ Oliver J. Stacey, ${ }^{\text {a Peter N. Horton, }}{ }^{\mathrm{b}}$ Simon J. Coles ${ }^{\mathrm{b}}$ and Simon J. A. Pope ${ }^{\mathrm{a} *}$

${ }^{a}$ School of Chemistry, Main Building, Cardiff University, Museum Avenue, Cardiff, United Kingdom, CF10 3AT. Tel: +44(0) 29 20879316, Fax: +44(0) 29 20874030,email: popesj@cardiff.ac.uk

${ }^{b}$ UK National Crystallographic Service, Chemistry, Faculty of Natural and Environmental Sciences, University of Southampton, Highfield, Southampton, SO17 1BJ, England

\begin{abstract}
The synthesis and characterisation of nine new monometallic heteroleptic platinum complexes $\left[\operatorname{PtCl}\left(\mathbf{L}^{\mathbf{1 - 3}}\right)(\mathrm{DMSO})\right],\left[\operatorname{Pt}\left(\mathbf{L}^{\mathbf{1 - 3}}\right)(\operatorname{acac})\right],\left[\operatorname{Pt}\left(\mathbf{L}^{\mathbf{1 - 3}}\right)(8-\mathrm{Q})\right]\left(\right.$ where $\mathbf{L}^{\mathbf{1 - 3}}=N$-octyl/dodecyl/hexadecyl-2phenylquinoline-4-carboxamides; acac $=$ acetylacetonate; $8-\mathrm{Q}=8$-quinolinato) are described. Single crystal X-ray diffraction studies on $\left[\operatorname{Pt}\left(\mathbf{L}^{\mathbf{1}}\right)(\right.$ acac) $\left.)\right]$ revealed a square planar coordination geometry with intermolecular Pt-Pt contacts at $c a .3 .3 \AA$. The complexes were investigated using ${ }^{195} \mathrm{Pt}\left\{{ }^{1} \mathrm{H}\right\}$ NMR spectroscopy, revealing varied chemical shifts around $\delta_{\mathrm{Pt}}-2800 \mathrm{ppm}$ that were strongly dependent upon the specific coordination environment of $\operatorname{Pt}(\mathrm{II})$. Luminescence studies showed the complexes possess a phosphorescent character with tuneable emission wavelengths between $605-641 \mathrm{~nm}$, and luminescent lifetimes up to $c a .450 \mathrm{~ns}$. Supporting TD-DFT studies provided descriptions of the HOMO and LUMO energy levels of the key complex types, which generally correlated well with the experimental spectra. The contribution of the $\operatorname{Pt}(5 d)$ centre to the calculated HOMOs was strongly ligand dependent, whilst the LUMOs were generally predicted to be localized over the quinoline component of the cyclometalated ligand.
\end{abstract}




\section{Introduction}

Cyclometelated platinum(II) complexes are highly attractive species to study due to their wide ranging optoelectronic and biomedical applications. ${ }^{1}$ There is an ever-expanding range of suitable ligands that can be coordinated to square planar $\mathrm{Pt}(\mathrm{II})$ in a cyclometalating manner. The relative ease of design, and attempts at tuning the resultant physical properties of the complex, have led to cyclometalated platinum complexes being studied in photocatalysis, ${ }^{2}$ photooxidation (via the photogeneration of $\left.{ }^{1} \mathrm{O}_{2}\right),{ }^{3}$ electroluminescent cells, ${ }^{4}$ luminescent bioimaging agents ${ }^{5}$ and optical sensors. ${ }^{6}$

Planar cyclometalated $\mathrm{Pt}(\mathrm{II})$ complexes have also recently been investigated with respect to the design of targeted agents for binding amyloid beta peptide, ${ }^{7}$ in the context of the inhibition of $\mathrm{Zn}$ and $\mathrm{Cu}$ peptide complex formation ( $c f$. Alzheimer's disease). These studies follow on from the detailed and lengthy history of the biomedical applications of square planar Pt(II) complexes, ${ }^{8}$ particularly with respect to the treatment of cancer (cisplatin). ${ }^{9}$ Since cisplatin and its analogues are regarded as non-luminescent, more recent approaches have looked at tethering fluorescent tags onto closely related $\mathrm{Pt}(\mathrm{II})$ species, thus enabling 'visualisation' of the biologically active Pt(II) species in a cellular environment. ${ }^{10}$ In this context cyclometalated $\mathrm{Pt}(\mathrm{II})$ species such as $\left.\left[\mathrm{Pt}\left(\mathrm{C}^{\wedge} \mathrm{N}\right)(\mathrm{DMSO}) \mathrm{Cl}\right)\right]$ (where $\mathrm{C}^{\wedge} \mathrm{N}=$ a cyclometalating unit) may have much to offer as we have shown that they can possess luminescent properties; ${ }^{11}$ the relatively labile co-ligands enable their application to cell imaging using confocal fluorescence microscopy and the development of prospective bimodal imaging agents. ${ }^{12}$ Indeed the assessment of the cytotoxic nature of related $\mathrm{Pt}(\mathrm{II})$ complexes is an area of intense study. ${ }^{13}$

The focus of this paper is the development of 2-phenyl-4-quinolinecarboxamido alkylderived ligands, which possess alkyl chain lengths of $n=8$ (octyl), 12 (dodecyl) and 16 (hexadecyl) $\mathbf{H L}^{\mathbf{1 - 3}}$, respectively, leading to nine new cyclometalated $\mathrm{Pt}(\mathrm{II})$ complexes of the type $[\mathrm{Pt}(\mathrm{L})(\mathrm{DMSO}) \mathrm{Cl})],[\mathrm{Pt}(\mathrm{L})(\mathrm{acac})]($ where acac = acetyacetonate) and $[\mathrm{Pt}(\mathrm{L})(8-\mathrm{Q})]($ where $8-\mathrm{Q}=8$ quinolinato). These ligands can be synthesised from commercially available cinchophen (2-phenyl- 
4-quinolinecarboxylic acid), and we have previously shown that derivatives of this ligand class can be used to develop related cyclometalated Ir(III) complexes with tuneable luminescent properties. ${ }^{14}$ The reasons for the incorporation of alkyl chains are two fold: firstly, to improve the organic solubility of the resultant $\mathrm{Pt}(\mathrm{II})$ species isolated as intermediates and thus facilitate further reactivity, and secondly, to allow for future consideration of these complexes as cellular bioimaging agents. Previous studies on luminescent rhenium(I) complexes functionalised with alkyl chains have shown that enhanced lipophilicity of organometallic complexes can dramatically improve transport across the cell membrane and aid intracellular distribution. ${ }^{15}$

It is also noteworthy that cinchophen-based species also have a long history of biomedical application. Cinchophen itself was used as an analgesic to treat gout in the early twentieth century, whilst 2-phenyl-4-quinolinecarboxamides have been investigated as therapeutics for neurological diseases, including schizophrenia. ${ }^{16}$

\section{Results and Discussion}
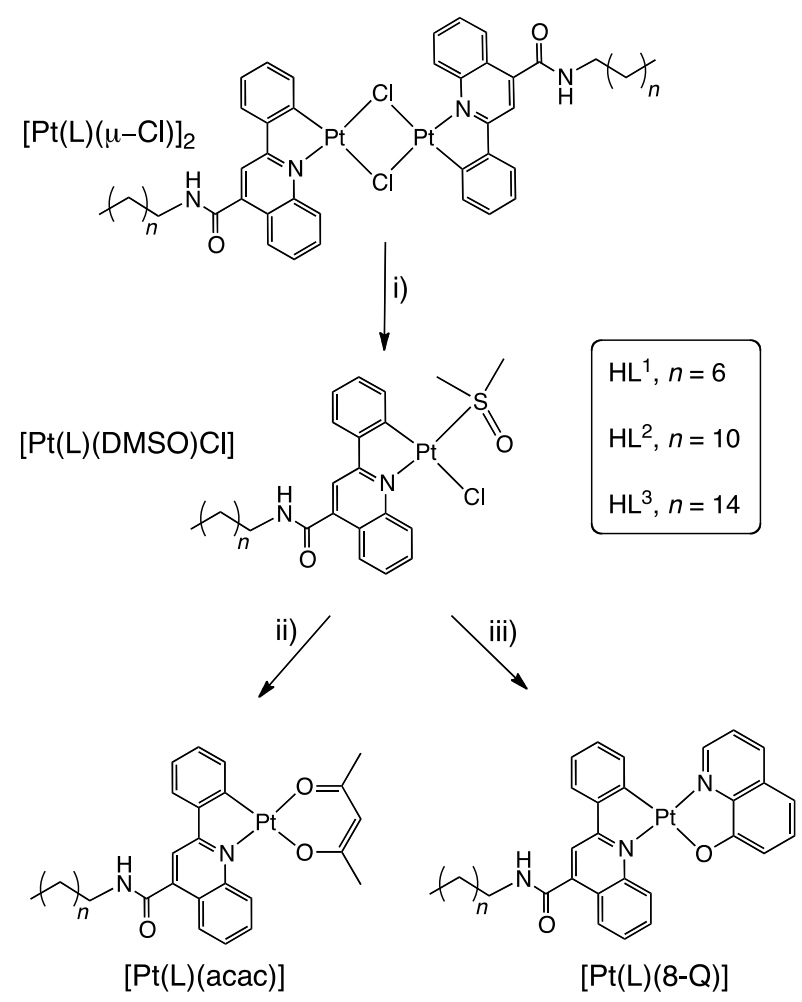
Scheme 1. Synthesis of the complexes: i) DMSO, rt; ii) 2,4-pentanedione, 3-pentanone; iii) 8hydroxyquinoline, 2-methoxyethanol.

\section{Synthesis of the ligands and complexes}

The ligands were prepared following previous reports for related amide-functionalised ligands based on the cinchophen structure. ${ }^{13}$ Thus, 2-phenyl-4-quinolinecarbonyl chloride was reacted with a series of $n$-alkyl amines with octyl, dodecyl and hexadecyl length chains to give the ligands $\mathbf{H L}^{\mathbf{1}}$, $\mathbf{H L}^{2}$ and $\mathbf{H L}^{3}$ respectively.

The complexes (Scheme 1) were synthesised according to our previous reports on related $\mathrm{Pt}(\mathrm{II})$ systems $^{11,12}$ which involves the generation of a precursor $\mathrm{Pt}(\mathrm{II})$ dimer species $[\mathrm{Pt}(\mathbf{L})(\mu-\mathrm{Cl})]_{2}$ which is then split by DMSO to give monometallic $[\mathrm{Pt}(\mathbf{L})(\mathrm{DMSO}) \mathrm{Cl}]$ allowing further reactivity and addition of co-ligands. The solubility characteristics of $\mathbf{H L}^{3}$ (hexadecyl) were incompatible with the aqueous reaction mixtures typically used for the synthesis of the $\mu$-dichloro-bridged $\mathrm{Pt}(\mathrm{II})$ dimers. Therefore, in this case, additional 2-ethoxyethanol was added in an attempt to improve the solubility of the ligand in the reaction medium. Despite this, the reaction yield for the dimer $\left[\operatorname{Pt}\left(\mathbf{L}^{3}\right)(\mu-C l)\right]_{2}$ was still lower than for $\mathbf{H L}^{\mathbf{1}}$ and $\mathbf{H L}^{\mathbf{2}}$, which is attributed to the highly hydrophobic character of the hexadecyl chain in $\mathbf{H L}^{3}$. In all three cases unreacted ligand was removed from the dimer material by washing the crude solid product with dichloromethane. The subsequent splitting of the dimers in DMSO yielded the monometallic [Pt(L)(DMSO)Cl] species which were isolated and spectroscopically characterised. The DMSO adducts were then reacted further with either 2,4pentanediketone to give $[\mathrm{Pt}(\mathbf{L})($ acac $)]$, or 8-hydroxyquinoline to give $[\operatorname{Pt}(\mathbf{L})(8-\mathrm{Q})]$.

\section{Characterisation of the ligands and complexes}

The ligands $\mathbf{H L}^{\mathbf{1 - 3}}$ were characterised using the traditional array of spectroscopic and analytical techniques. ${ }^{1} \mathrm{H}$ NMR spectroscopy revealed that the amide $\mathrm{N} H$ proton of the ligands appears as a broadened triplet between $6.37-6.93$ ppm, depending upon the alkyl chain length. ${ }^{13} \mathrm{C}\left\{{ }^{1} \mathrm{H}\right\} \mathrm{NMR}$ 
spectroscopy showed overlapping resonances in the aliphatic regions associated with the alkyl chains of the ligands and thus fewer signals than theoretically predicted.

Typically, for the ${ }^{1} \mathrm{H}$ NMR spectra of $[\mathrm{Pt}(\mathbf{L})(\mathrm{DMSO}) \mathrm{Cl}]$ the methyl resonance of the coordinated DMSO appeared around $\delta_{\mathrm{H}} 3.6 \mathrm{ppm}$ with satellites attributed to coupling to the ${ }^{195} \mathrm{Pt}$ nucleus. The $[\mathrm{Pt}(\mathbf{L})(\mathrm{acac})]$ complexes revealed the singlet resonance at $\delta_{\mathrm{H}} 5.6 \mathrm{ppm}$ associated with the coordinated acac ligand. ${ }^{195} \mathrm{Pt}\left\{{ }^{1} \mathrm{H}\right\}$ NMR spectra obtained for the three $[\mathrm{Pt}(\mathbf{L})(\mathrm{acac})]$ complexes each appeared around $\delta \mathrm{Pt}-2775 \mathrm{ppm}$ suggesting that alteration of the alkyl chain length had very little effect upon the $\mathrm{Pt}(\mathrm{II})$ centre. This value for $\delta_{\mathrm{Pt}}$ is consistent with our previous reports on related cinchophen-derived complexes of Pt(II) $)^{11,12}$ and very close to the reported chemical shift for the benchmark analogue $[\mathrm{Pt}(\mathrm{ppy})(\mathrm{acac})]$ (where ppy $=2$-phenylquinoline) at $-2868 \mathrm{ppm} .{ }^{17} \mathrm{The}{ }^{195} \mathrm{Pt}$ resonances for the remaining complexes were all consistent with our previous studies on related $\mathrm{Pt}$ complexes of this type. ${ }^{11}$ Mass spectrometry studies on the $[\operatorname{Pt}(\mathbf{L})(\operatorname{acac})]$ complexes generally showed a $[\mathrm{M}-\mathrm{H}]^{-}$cluster of peaks matching the predicted isotopic distribution; $[\mathrm{Pt}(\mathbf{L})(8-\mathrm{Q})]$ complexes revealed a $[\mathrm{M}+\mathrm{Na}]^{+}$cluster of peaks, again with the appropriate isotopic distribution for $\mathrm{Pt}$. The $[\mathrm{Pt}(\mathbf{L})(\mathrm{DMSO}) \mathrm{Cl}]$ species were, unsurprisingly, prone to fragmentation and loss of ligand; typical $\mathrm{m} / \mathrm{z}$ values revealed the expected isotopic pattern for $\mathrm{Pt}$, but with a loss of both chloride and DMSO ligands upon ionisation.

\section{X-ray crystal structure of $\left[\operatorname{Pt}\left(L^{1}\right)(\operatorname{acac})\right]$}

X-ray crystallographic studies were undertaken on suitable crystals of $\left[\operatorname{Pt}\left(\mathbf{L}^{\mathbf{1}}\right)(\mathrm{acac})\right]$ which were obtained by the slow evaporation of a concentrated chloroform solution of the complex. The structure (Figure 1) revealed the expected coordination sphere with a weakly distorted square planar geometry at $\mathrm{Pt}(\mathrm{II})$. The bond lengths around the Pt centre were found to be 1.952(6) and 2.041(5) $\AA$ for the Pt-C and Pt-N bonds, respectively, and 2.006(4) and 2.089(4) $\AA$ for the Pt-O bond lengths (where the shorter bond is trans to the coordinated $\mathrm{N}$ atom). These are very comparable to the bond lengths reported for the structure of the related complex $[\operatorname{Pt}(\mathrm{ppy})(\mathrm{acac})]$, as well as being in line 
with our previous observations on related cinchophen derived Pt(II) complexes. ${ }^{11,12}$ There is a headto-tail packing arrangement of the complexes within the crystal form, driven by the formation of dimers through a Pt-Pt interaction of 3.327(1) $\AA$ (and therefore below the sum of the van der Waal's radii). ${ }^{18}$

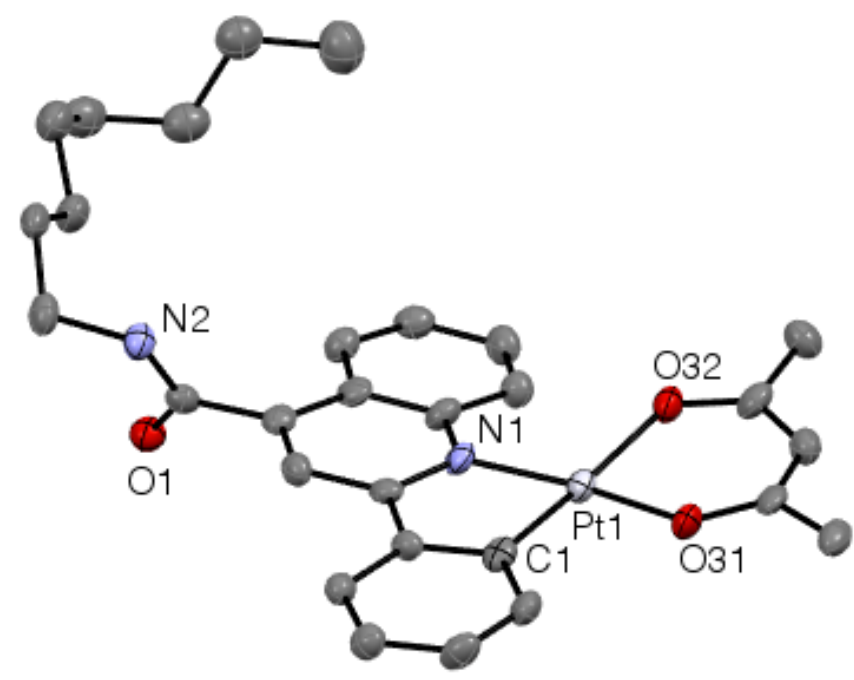

Figure 1. X-ray crystal structure of $\left[\operatorname{Pt}\left(\mathbf{L}^{1}\right)\right.$ (acac)]. Ellipsoids are drawn at $50 \%$ probability and $\mathrm{H}$ atoms and solvent molecules are omitted. Crystal data for [Pt(L1)(acac)]: $\mathrm{C}_{30} \mathrm{H}_{35} \mathrm{Cl}_{3} \mathrm{~N}_{2} \mathrm{O}_{3} \mathrm{Pt}, M=$ 773.04, red plate, $a=14.0542(10), b=8.3288(5), c=25.6474(18) \AA, \alpha=90, \beta=93.606(2), \gamma=90$, $\mathrm{V}=2996.2(3) \AA^{3}$, monoclinic, space group $P 2{ }_{1} / n, Z=4, \mu=4.985 \mathrm{~mm}^{-1}$, reflections collected = 30031 , independent reflections $=6837, \mathrm{R}_{\text {int }}=0.1338, \mathrm{R} 1=0.0448, \mathrm{wR} 2\left[F^{2}>2 \sigma\left(F^{2}\right)\right]=0.0784, \mathrm{R} 1$ $=0.0713, \mathrm{wR} 2=0.0825$.

\section{UV-vis. absorption and luminescence studies}

The electronic absorption spectra of the free ligands (in chloroform) were dominated by the expected ${ }^{1} \pi-\pi^{*}$ transitions typical of a phenylquinoline chromophore; each ligand possesses two peaks at around 332 and $264 \mathrm{~nm}$. The UV-vis absorption data for all complexes is collected in Table 1. For the $[\mathrm{Pt}(\mathbf{L})(\mathrm{DMSO}) \mathrm{Cl}]$ complexes the UV-vis spectra (in chloroform) displayed bathochromically shifted features with a peak at $c a .285 \mathrm{~nm}$ attributed to ligand-centred ${ }^{1} \pi-\pi^{*}$ 
transitions and a broad, lower intensity band ca. $365 \mathrm{~nm}$ with a weak shoulder at $420 \mathrm{~nm}$. Conversion to the $[\operatorname{Pt}(\mathbf{L})(\mathrm{acac})]$ revealed spectra (in chloroform) which retain the ligand-centred features, but modulate the appearance of the broad visible absorption band at 400-500 nm (for example, Figure 2). Notably for the $[\mathrm{Pt}(\mathbf{L})(8-\mathrm{Q})]$ species an additional absorption feature was displayed in the visible part of the spectrum at $450-575 \mathrm{~nm}$. The results show that the length of the alkyl chain (octyl, dodecyl, hexadecyl) imparts little influence on the energies of the absorption bands, which is consistent with the expected similarities in electronic structure for these complexes.

Supporting theoretical TD-DFT calculations on closely related cyclometalated Pt(II) model complexes (based on cyclometalating $\mathrm{L}=$ ethyl-2-phenylquinoline-4-carboxylate) show that the nature of the HOMO-LUMO transitions are likely to vary according to the ancillary ligands at $\mathrm{Pt}(\mathrm{II})$ (see Table 1). In particular, the studies show that the calculated percentage of $\mathrm{Pt} 5 d$ orbital contribution to the HOMO varies significantly across the series $[\mathrm{Pt}(\mathbf{L})(\mathrm{DMSO}) \mathrm{Cl}]$ versus $[\operatorname{Pt}(\mathbf{L})($ acac $)]$ versus $[\mathrm{Pt}(\mathbf{L})(8-\mathrm{Q})]$. Thus, for $[\mathrm{Pt}(\mathbf{L})(8-\mathrm{Q})]$ complexes, where the percentage of $\mathrm{Pt} 5 d$ character contributing to the HOMO is calculated to be $<5 \%$, ligand(quinolinato)-toligand(quinoline) charge transfer (LLCT) transitions are predicted to contribute to the HOMOLUMO transition. This predicted transition probably corresponds to the experimentally observed lowest energy absorption at $450-575 \mathrm{~nm}$ for the $[\mathrm{Pt}(\mathbf{L})(8-\mathrm{Q})]$ complexes. In comparison, for the $[\operatorname{Pt}(\mathbf{L})($ acac $)]$ species, the percentage of $\mathrm{Pt} 5 d$ character contributing to the HOMO is calculated to be $c a .40 \%$, suggesting a greater metal(platinum)-to-ligand(quinoline) charge transfer (MLCT) contribution to the visible absorption band of $[\mathrm{Pt}(\mathbf{L})(\mathrm{acac})]$. 


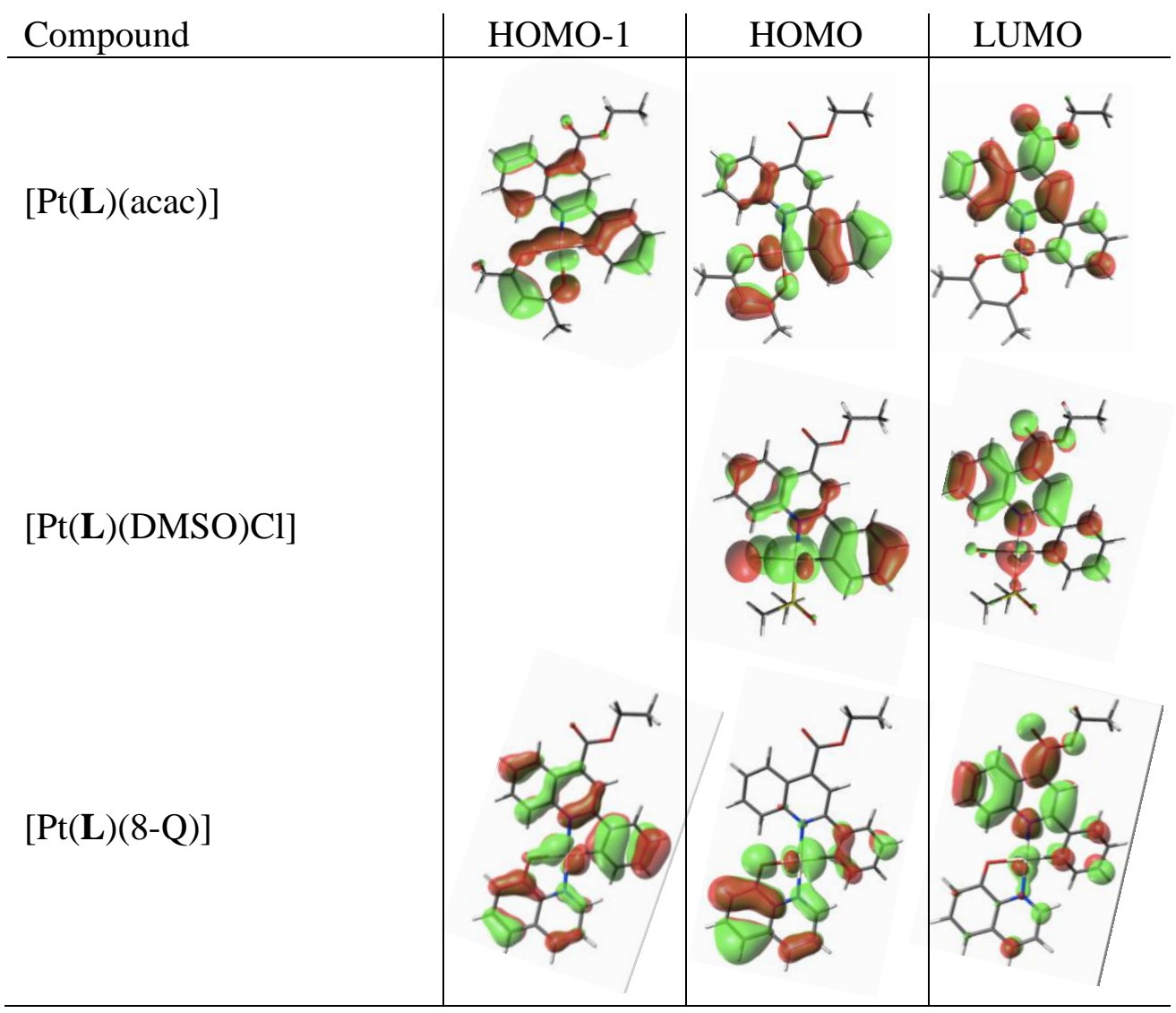

Table 1. Calculated frontier orbitals for $[\mathrm{Pt}(\mathbf{L})(\mathrm{acac})]$, $[\mathrm{Pt}(\mathbf{L})(\mathrm{DMSO}) \mathrm{Cl}]$ and $[\mathrm{Pt}(\mathbf{L})(8-\mathrm{Q})]$ complexes (where L = ethyl-2-phenylquinoline-4-carboxylate).

All of the complexes were shown to be luminescent in chloroform solution following excitation in the visible region at $420 \mathrm{~nm}$ (Table 1). The broad featureless emission profiles occur between $590-$ $640 \mathrm{~nm}$ and were clearly dependent upon the nature of the ancillary ligands coordinated to $\mathrm{Pt}(\mathrm{II})$ (Figure 3). In the case of $[\operatorname{Pt}(\mathbf{L})(\mathrm{acac})]$ species the alkyl chain length does not impart any shift in emission energy. A comparison of the $[\operatorname{Pt}(\mathbf{L})(\mathrm{acac})]$ and $[\operatorname{Pt}(\mathbf{L})(8-\mathrm{Q})]$ species show that the former possess a longer emission wavelength and thus larger Stokes' shift compared to the latter. The luminescence lifetimes of the $[\operatorname{Pt}(\mathbf{L})(\operatorname{acac})]$ and $[\operatorname{Pt}(\mathbf{L})(8-Q)]$ complexes were in the range 211-439 
ns and thus consistent with a phosphorescent emitting state that is likely to comprise admixtures of ${ }^{3} \mathrm{MLCT} /{ }^{3} \mathrm{LLCT}$. The $[\mathrm{Pt}(\mathbf{L})(\mathrm{acac})]$ complexes clearly displayed significantly longer lifetimes than the 8-quinolinato analogues. The corresponding lifetimes of the precursor $[\mathrm{PtCl}(\mathbf{L})(\mathrm{DMSO})]$ species are notably shorter (24-54 ns) suggesting a more pronounced quenching of the excited state, due to the coordinated DMSO and chloride ligands, the latter known to contribute to quenching in certain metal complexes. ${ }^{19}$ Quantum yields in aerated solvent were modest $(\leq 1 \%)$ but in line with previous studies on this class of complex. ${ }^{11}$

Table 2. UV-vis and luminescence spectroscopic data for the complexes (in aerated chloroform).

\begin{tabular}{|c|c|c|c|c|}
\hline Complex & $\begin{array}{c}\text { Absorption } \\
\left(\lambda_{\max } / \mathbf{n m}\right)\end{array}$ & $\begin{array}{c}\text { Emission } \\
\left(\lambda_{\mathrm{em}} / \mathbf{n m m}\right)^{a}\end{array}$ & $\begin{array}{l}\text { Lifetime } \\
(\tau / \mathbf{n s})^{b}\end{array}$ & $\begin{array}{l}\text { Quantum } \\
\text { Yield }^{c}\end{array}$ \\
\hline$\left[\operatorname{Pt}\left(\mathbf{L}^{\mathbf{1}}\right)(\mathrm{DMSO}) \mathrm{Cl}\right]$ & $272,281,341,368,422 \mathrm{sh}$ & 609 & 24 & - \\
\hline$\left[\operatorname{Pt}\left(\mathbf{L}^{\mathbf{1}}\right)(\mathrm{acac})\right]$ & $300,349,368,417$ & 618 & 380 & 0.006 \\
\hline$\left[\operatorname{Pt}\left(\mathbf{L}^{\mathbf{1}}\right)(8-Q)\right]$ & $263,370,505$ & 606 & 211 & 0.004 \\
\hline$\left[\mathrm{Pt}\left(\mathbf{L}^{2}\right)(\mathrm{DMSO}) \mathrm{Cl}\right]$ & $281,363,430 \mathrm{sh}$ & 615 & 54 & - \\
\hline$\left[\operatorname{Pt}\left(\mathbf{L}^{2}\right)(\operatorname{acac})\right]$ & $284,345,368,415$ & 617 & 406 & 0.01 \\
\hline$\left[\operatorname{Pt}\left(\mathbf{L}^{2}\right)(8-Q)\right]$ & $265,269,368,502$ & 606 & 238 & 0.005 \\
\hline$\left[\mathrm{Pt}\left(\mathbf{L}^{\mathbf{3}}\right)(\mathrm{DMSO}) \mathrm{Cl}\right]$ & $265,284,365,426 \mathrm{sh}$ & 592 & 28 & - \\
\hline$\left[\operatorname{Pt}\left(\mathbf{L}^{\mathbf{3}}\right)(\mathrm{acac})\right]$ & $259,286,295,344,361,414$ & 617 & 439 & 0.01 \\
\hline$\left[\operatorname{Pt}\left(\mathbf{L}^{\mathbf{3}}\right)(8-\mathrm{Q})\right]$ & $283,346,362,429,496$ & 593 & 227 & 0.004 \\
\hline
\end{tabular}

\footnotetext{
${ }^{a}$ using $420 \mathrm{~nm}$ excitation; ${ }^{b}$ using 295 or $372 \mathrm{~nm}$ excitation; c using $\left[\mathrm{Ru}(\text { bipy })_{3}\right]\left(\mathrm{PF}_{6}\right)_{2}$ in aerated $\mathrm{MeCN}$ as standard $(\Phi=0.016) .^{20}$
} 


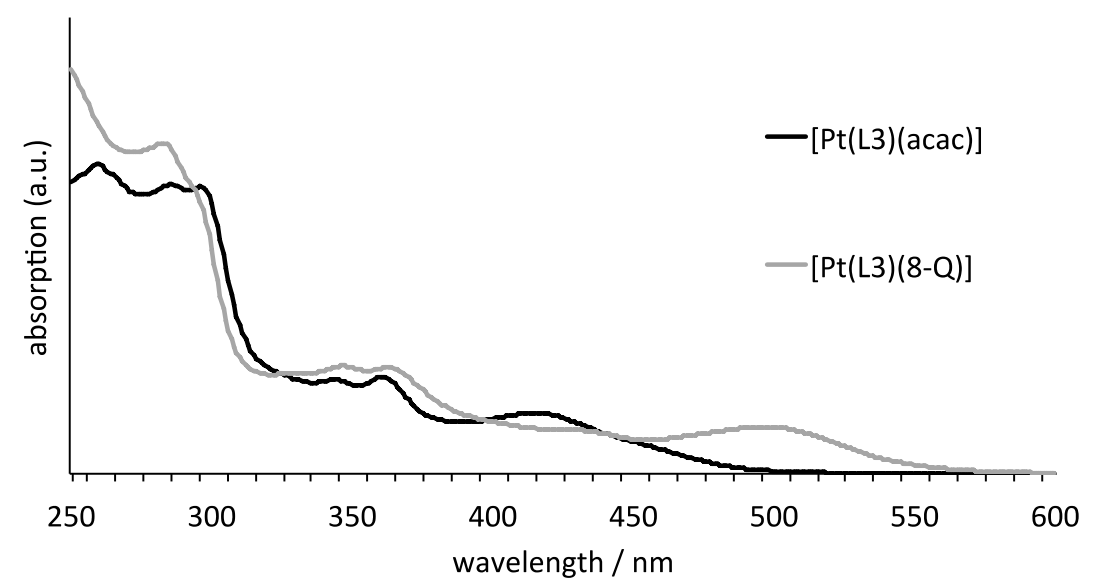

Figure 2. UV-vis absorption spectra comparing $\left[\mathrm{Pt}\left(\mathbf{L}^{\mathbf{3}}\right)(\mathrm{acac})\right]$ (black line) and $\left[\mathrm{Pt}\left(\mathbf{L}^{\mathbf{3}}\right)(8-\mathrm{Q})\right]$ (grey line) (in chloroform).
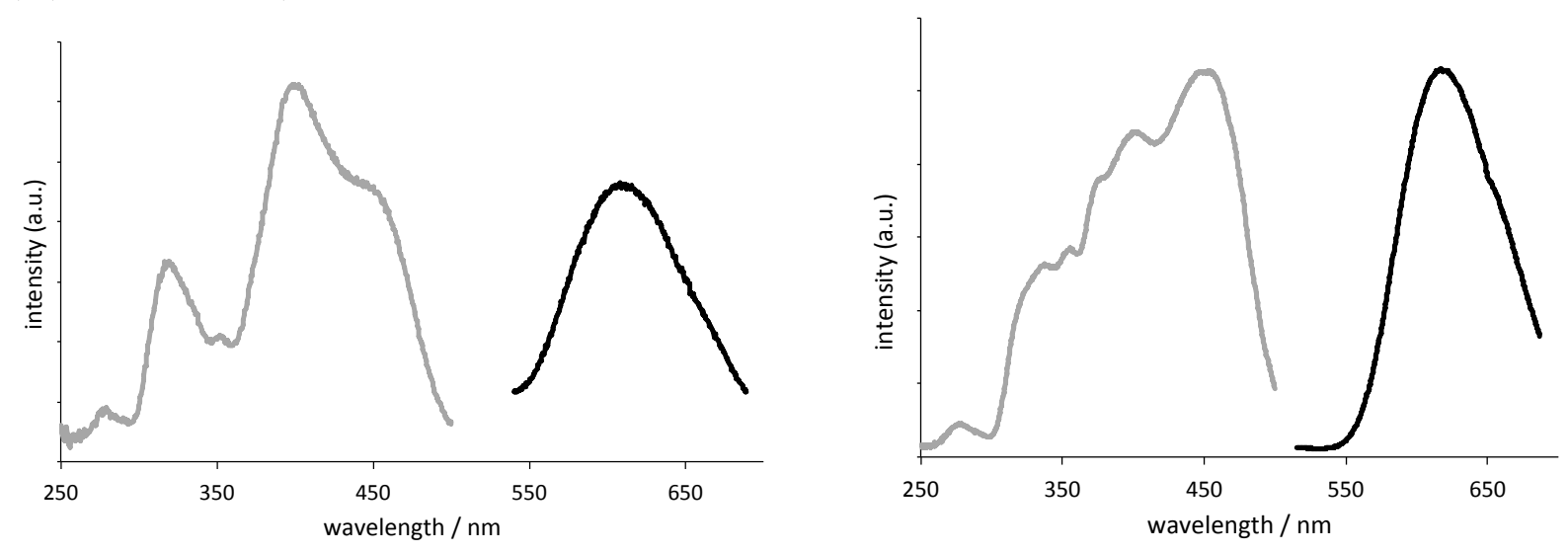

Figure 3. Normalised excitation (grey) and emission (black) spectra for $\left[\operatorname{Pt}\left(\mathbf{L}^{\mathbf{3}}\right)(8-\mathrm{Q})\right]$ (left) and $\left[\operatorname{Pt}\left(\mathbf{L}^{3}\right)\right.$ (acac)] (right) (aerated chloroform, $\lambda_{\mathrm{ex}}=420 \mathrm{~nm}$ ).

\section{Conclusions}

The work has shown that highly lipophilic cyclometalated Pt(II) complexes can be synthesised from carboxamide derivatives of 2-phenylquinoline. Supporting spectroscopic and X-ray structural data show that the complexes possess the anticipated formulations. The stepwise synthesis of the complexes allow a range of ancillary ligands to be coordinated to $\mathrm{Pt}(\mathrm{II})$ enabling tuning of the absorption and emission properties of the complexes. The addition of an 8-quinolinato chelate 
$[\mathrm{Pt}(\mathbf{L})(8-\mathrm{Q})]$ results in a bathochromically shifted absorption whilst the emission is at a higher energy relative to the $[\operatorname{Pt}(\mathbf{L})($ acac $)]$ species. The acac complexes also display the longest phosphorescent lifetimes in this series of complexes, with values up to 439 ns. Generally, the electronic effect of the alkyl chain is neglible with chain length differences imparting only minor variations in the photophysical parameters. Given the promising nature of the luminescence properties, future studies will explore the cell imaging potential of this series of complexes with particular attention on the cellular uptake characteristics of these highly lipophilic complexes.

\section{Experimental}

All reactions were performed with the use of vacuum line and Schlenk techniques. Reagents were commercial grade and were used without further purification. ${ }^{1} \mathrm{H}$ and ${ }^{13} \mathrm{C}\left\{{ }^{1} \mathrm{H}\right\}$ NMR spectra were run on NMR-FT Bruker 250 or 400 spectrometers, ${ }^{195} \mathrm{Pt}\left\{{ }^{1} \mathrm{H}\right\}$ on NMR-FT 500 spectrometer all recorded in $\mathrm{CDCl}_{3} .{ }^{1} \mathrm{H}$ and ${ }^{13} \mathrm{C}\left\{{ }^{1} \mathrm{H}\right\}$ NMR chemical shifts $(\delta)$ were determined relative to internal TMS and are given in ppm. Low-resolution mass spectra were obtained by the staff at Cardiff University. High-resolution mass spectra were carried out by at the EPSRC National Mass Spectrometry Service at Swansea University. UV-Vis studies were performed on a Jasco V-570 spectrophotometer as chloroform solutions. Photophysical data were obtained on a JobinYvonHoriba Fluorolog spectrometer fitted with a JY TBX picosecond photodetection module as chloroform solutions. Emission spectra were uncorrected and excitation spectra were instrument corrected. The pulsed source was a Nano-LED configured for $372 \mathrm{~nm}$ output operating at $1 \mathrm{MHz}$. Luminescence lifetime profiles were obtained using the JobinYvon-Horiba FluoroHub single photon counting module and the data fits yielded the lifetime values using the provided DAS6 deconvolution software.

\section{X-ray data collection and processing}

Suitable crystals were selected and data collected following a standard method, ${ }^{21}$ on a Rigaku RAXIS Spider molybdenum sealed tube diffractometer at 120K equipped with a RAPID image plate 
detector. Cell determination and data collection were carried out using CrystalClear. ${ }^{22}$ Structure solution and refinement using SHELX programs. ${ }^{23}$ CCDC 1432127 contains supplementary X-ray crystallographic data for $\left[\operatorname{Pt}\left(\mathbf{L}^{\mathbf{1}}\right)(\mathrm{acac})\right]$. This data can be obtained free of charge via http://www.ccdc.cam.ac.uk/conts/retrieving.html, or from the Cambridge Crystallographic Data Centre, Union Road, Cambridge, CB2 1EZ; fax $(+44)$ 1223-336-033 or email: deposit@ccdc.cam.ac.uk.

\section{DFT studies}

Non-relativistic calculations were performed on the Gaussian 09 program. ${ }^{24}$ Geometry optimisations were carried out without constraints using the B3LYP functional. ${ }^{25}$ The StuttgartDresden basis set was used for the Pt atoms, ${ }^{26}$ and was invoked with pseudo-potentials for the core electrons, with a 6-31G(d) basis set for all remaining atoms. ${ }^{27}$ TD-DFT studies were performed using the same functional, but with $6-31+\mathrm{G}(\mathrm{d}, \mathrm{p})$ on all non-metal atoms, and also included a simulated $\mathrm{MeCN}$ environment using the polarized continuum model (PCM) approach. ${ }^{28}$ For prediction of absorption spectra, the geometry used to calculate orbital and other properties was used without modification. For the prediction of emission energies, however, the triplet state was allowed to relax to its optimal geometry using unrestricted B3LYP in the gas phase, prior to solvated TD-DFT.

\section{Materials}

2-phenyl-4-quinolinecarboxylic acid and potassium tetrachloroplatinate were used as purchased from Alfa Aesar.

\section{Synthesis}

Synthesis of HL' ${ }^{1}$ : Thionyl chloride (excess) was added, dropwise, to a stirring suspension of 2phenyl-4-quinolinecarboxylic acid $(0.465 \mathrm{~g}, 1.869 \mathrm{mmol})$ in chloroform (10 $\mathrm{mL})$. The reaction was 
heated at reflux for $16 \mathrm{~h}$ under dinitrogen. The solvent was then removed in vacuo and the yellow solid redissolved in chloroform $(10 \mathrm{~mL})$ before the selected 1-octylamine $(0.219 \mathrm{~g}, 1.699 \mathrm{mmol})$ was added dropwise to the stirring solution. $\operatorname{EtN}^{i} \operatorname{Pr}_{2}$ (excess) was added dropwise and the mixture was stirred for $16 \mathrm{~h}$ at room temperature under dinitrogen. The solvent was removed in vacuo before being redissolved in dichloromethane $(20 \mathrm{~mL})$. The crude mixture was washed with aqueous $\mathrm{NaHCO}_{3}$ (sat. $2 \times 20 \mathrm{~mL}$ ), water $(1 \times 20 \mathrm{~mL})$ and brine $(1 \times 20 \mathrm{~mL})$. The organic phase was collected, dried over $\mathrm{MgSO}_{4}$ and filtered before the solvent was removed in vacuo. Yield $=0.434 \mathrm{~g}$ (71\%). ${ }^{1} \mathrm{H}$ NMR $\left(400 \mathrm{MHz}, \mathrm{CDCl}_{3}\right): \delta_{\mathrm{H}} 7.98\left(1 \mathrm{H}, \mathrm{d},{ }^{3} \mathrm{~J}_{\mathrm{HH}}=8.4 \mathrm{~Hz}\right), 7.94-7.91(2 \mathrm{H}, \mathrm{m}), 7.84(1 \mathrm{H}$, $\left.\mathrm{d},{ }^{3} \mathrm{~J}_{\mathrm{HH}}=8.0 \mathrm{~Hz}\right), 7.60-7.56(1 \mathrm{H}, \mathrm{m}), 7.51(1 \mathrm{H}, \mathrm{s}), 7.42-7.40(3 \mathrm{H}, \mathrm{m}), 7.33-7.29(1 \mathrm{H}, \mathrm{m}), 6.93$ $\left(1 \mathrm{H}\right.$, br. t, $\left.{ }^{3} J_{\mathrm{HH}}=4.4 \mathrm{~Hz}\right), 3.35-3.30(2 \mathrm{H}, \mathrm{m}), 1.59-1.52(2 \mathrm{H}, \mathrm{m}), 1.34-1.19(10 \mathrm{H}, \mathrm{m}), 0.90(3 \mathrm{H}$, $\left.\mathrm{t},{ }^{3} \mathrm{~J}_{\mathrm{HH}}=6.4 \mathrm{~Hz}\right) \mathrm{ppm} .{ }^{13} \mathrm{C}\left\{{ }^{1} \mathrm{H}\right\} \mathrm{NMR}\left(75.6 \mathrm{MHz}, \mathrm{CDCl}_{3}\right): \delta_{\mathrm{C}} 167.6,156.7,148.5,143.4,138.7$, $130.3,129.9,129.0,127.5,127.3,125.1,123.4,116.4,40.3,31.9,29.7,29.4,27.1,22.8,14.2$ ppm. $\operatorname{MS}(\mathrm{ES})$ found $m / z=361.22$ for $[\mathrm{M}+\mathrm{H}]^{+}$. UV-vis $\left(\mathrm{CHCl}_{3}\right): \lambda_{\max }\left(\varepsilon / \mathrm{dm}^{3} \mathrm{~mol}^{-1} \mathrm{~cm}^{-1}\right) 263(29100)$, 327 (6600) nm. IR (thin film): $v_{\max } 3306(\mathrm{~N}-\mathrm{H}), 1636(\mathrm{C}=\mathrm{O}) \mathrm{cm}^{-1}$.

Synthesis of $\mathbf{H L}^{2}$ : as for $\mathrm{HL}^{1}$, but using 2-phenyl-4-quinolinecarboxylic acid $(0.370 \mathrm{~g}, 1.486$ mmol) and 1-dodecylamine (0.250 g, $1.351 \mathrm{mmol})$. Yield $=0.416 \mathrm{~g}(74 \%) .{ }^{1} \mathrm{H}$ NMR $(400 \mathrm{MHz}$, $\left.\mathrm{CDCl}_{3}\right): \delta_{\mathrm{H}} 8.13\left(1 \mathrm{H}, \mathrm{d},{ }^{3} J_{\mathrm{HH}}=8.0 \mathrm{~Hz}\right), 8.09-8.06(3 \mathrm{H}, \mathrm{m}), 7.77(1 \mathrm{H}, \mathrm{s}), 7.73-7.69(1 \mathrm{H}, \mathrm{m}), 7.52$ $-7.46(4 \mathrm{H}, \mathrm{m}), 6.37\left(1 \mathrm{H}\right.$, br. $\left.\mathrm{t},{ }^{3} \mathrm{~J}_{\mathrm{HH}}=4.4 \mathrm{~Hz}\right), 3.54-3.49(2 \mathrm{H}, \mathrm{m}), 1.71-1.63(2 \mathrm{H}, \mathrm{m}), 1.42-$ $1.22(18 \mathrm{H}, \mathrm{m}), 0.88\left(3 \mathrm{H}, \mathrm{t},{ }^{3} J_{\mathrm{HH}}=6.4 \mathrm{~Hz}\right) \mathrm{ppm} .{ }^{13} \mathrm{C}\left\{{ }^{1} \mathrm{H}\right\} \mathrm{NMR}\left(75.6 \mathrm{MHz}, \mathrm{CDCl}_{3}\right): \delta_{\mathrm{C}} 167.6$, $156.7,148.4,143.5,138.6,130.3,129.9,129.0,127.6,127.4,125.1,123.5,116.5,68.2,40.3,32.0$, 29.7, 29.4, 29.3, 27.1, 22.8, $14.2 \mathrm{ppm}$. MS(ES) found $m / z=417.32$ for $[\mathrm{M}+\mathrm{H}]^{+}$. HR MS found $m / z$ $=417.2898 ; \mathrm{C}_{28} \mathrm{H}_{37} \mathrm{~N}_{2} \mathrm{O}$ requires 417.2900. UV-vis $\left(\mathrm{CHCl}_{3}\right): \lambda_{\max }\left(\varepsilon / \mathrm{dm}^{3} \mathrm{~mol}^{-1} \mathrm{~cm}^{-1}\right) 268(27500)$, $322(6000) \mathrm{nm}$. IR (thin film): $v_{\max } 3306(\mathrm{~N}-\mathrm{H}), 1636(\mathrm{C}=\mathrm{O}) \mathrm{cm}^{-1}$. 
Synthesis of $\mathbf{H L}^{3}$ : as for $\mathrm{HL}^{1}$, using 2-phenyl-4-quinolinecarboxylic acid $(0.454 \mathrm{~g}, 1.826 \mathrm{mmol})$ and 1-hexadecylamine $(0.4 \mathrm{~g}, 1.660 \mathrm{mmol})$. Yield $=0.572 \mathrm{~g}(73 \%) .{ }^{1} \mathrm{H}$ NMR $\left(400 \mathrm{MHz}, \mathrm{CDCl}_{3}\right)$ : $\delta_{\mathrm{H}} 8.12-8.04(4 \mathrm{H}, \mathrm{m}), 7.75(1 \mathrm{H}, \mathrm{s}), 7.72-7.68(1 \mathrm{H}, \mathrm{m}), 7.51-7.45(4 \mathrm{H}, \mathrm{m}), 6.50\left(1 \mathrm{H}, \mathrm{br} . \mathrm{t},{ }^{3} J_{\mathrm{HH}}\right.$ $=4.4 \mathrm{~Hz}), 3.52-3.46(2 \mathrm{H}, \mathrm{m}), 1.69-1.61(2 \mathrm{H}, \mathrm{m}), 1.41-1.19(24 \mathrm{H}, \mathrm{m}), 0.87\left(3 \mathrm{H}, \mathrm{t},{ }^{3} J_{\mathrm{HH}}=6.8\right.$ Hz) ppm. ${ }^{13} \mathrm{C}\left\{{ }^{1} \mathrm{H}\right\} \mathrm{NMR}\left(75.6 \mathrm{MHz}, \mathrm{CDCl}_{3}\right): \delta_{\mathrm{C}} 167.6,156.6,148.5,143.3,138.7,130.1,129.9$, $129.8,128.9,127.6,127.5,127.2,125.1,123.4,116.3,53.5,40.3,32.0,29.8,29.7,29.5,29.1,27.1$, 22.8, $14.2 \mathrm{ppm}$. MS(ES) found $\mathrm{m} / z=473.34$ for $[\mathrm{M}+\mathrm{H}]^{+}$. UV-vis $\left(\mathrm{CHCl}_{3}\right): \lambda_{\max }\left(\varepsilon / \mathrm{dm}^{3} \mathrm{~mol}^{-1} \mathrm{~cm}^{-}\right.$ 1) 257 (76000), $324(28500) \mathrm{nm}$. IR (thin film): $v_{\max } 3306(\mathrm{~N}-\mathrm{H}), 1633(\mathrm{C}=\mathrm{O}) \mathrm{cm}^{-1}$.

Synthesis of $\left[\mathbf{P t}\left(\mathbf{L}^{\mathbf{1}}\right)(\boldsymbol{\mu}-\mathbf{C l})\right]_{2}$ : using potassium tetrachloroplatinate $(0.057 \mathrm{~g}, 0.137 \mathrm{mmol})$ and $\mathbf{H L 1}$ $(0.050 \mathrm{~g}, 0.139 \mathrm{mmol})$. A solution of potassium tetrachloroplatinate(II) (1.0 eq.) in water (2 mL) was added to a stirring solution of $\mathbf{H L}$ (1.0 eq.) in 2-ethoxyethanol (6 mL) under dinitrogen and heated to $80{ }^{\circ} \mathrm{C}$ for $16 \mathrm{~h}$ in a foil-wrapped flask. Brine $(10 \mathrm{~mL})$ was added to the cooled solution and the resultant precipitate was collected on a sinter and washed with water $(2 \times 10 \mathrm{~mL})$ and dried. The precipitate was washed with dichloromethane to remove any unreacted ligand. Yield $=0.070 \mathrm{~g}$ $(87 \%)$.

Synthesis of $\left[\mathbf{P t}\left(\mathbf{L}^{2}\right)(\boldsymbol{\mu}-\mathbf{C l})\right]_{2}$ : as for $\left[\mathrm{Pt}\left(\mathrm{L}^{1}\right)(\mu-\mathrm{Cl})\right]_{2}$, but using potassium tetrachloroplatinate $(0.050$ $\mathrm{g}, 0.120 \mathrm{mmol})$ and $\mathbf{H L}^{2}(0.050 \mathrm{~g}, 0.120 \mathrm{mmol})$. The solvent ratio was adjusted to $4: 1$ by using 8 $\mathrm{mL}$ of 2-ethoxyethanol. The precipitate was washed with dichloromethane to remove any unreacted ligand. Yield $=0.068 \mathrm{~g}(87 \%)$.

Synthesis of $\left[\mathbf{P t}\left(\mathbf{L}^{3}\right)(\boldsymbol{\mu}-\mathbf{C l})\right]_{2}$ : as for $\left[\mathrm{Pt}\left(\mathrm{L}^{1}\right)(\mu-\mathrm{Cl})\right]_{2}$, but using potassium tetrachloroplatinate $(0.097$ $\mathrm{g}, 0.233 \mathrm{mmol})$ and $\mathbf{H L}^{3}(0100 \mathrm{~g}, 0.212 \mathrm{mmol})$. The solvent ratio was adjusted to $4: 1$ by using 8 $\mathrm{mL}$ of 2-ethoxyethanol. The precipitate was washed with dichloromethane to remove any unreacted ligand. Yield $=0.095 \mathrm{~g}(64 \%)$. 
Synthesis of $\left[\mathbf{P t}\left(\mathbf{L}^{\mathbf{1}}\right)(\mathbf{D M S O}) \mathbf{C l}\right]$ : Based on a modified literature methodology. ${ }^{29}$ Crude $[\operatorname{Pt}(\mathbf{L 1})(\mu-$ $\mathrm{Cl})]_{2}(0.070 \mathrm{~g}, 0.059 \mathrm{mmol})$ was dissolved in a minimum volume of DMSO before being precipitated with brine $(10 \mathrm{~mL})$, filtered on a sinter, washed with water $(2 \times 20 \mathrm{~mL})$ and then dried. Yield $=0.044 \mathrm{~g}(55 \%) .{ }^{1} \mathrm{H}$ NMR $\left(400 \mathrm{MHz}, \mathrm{CDCl}_{3}\right): \delta_{\mathrm{H}} 8.95\left(1 \mathrm{H}, \mathrm{d},{ }^{3} J_{\mathrm{HH}}=8.8 \mathrm{~Hz}\right), 8.29-8.27$ $\left(1 \mathrm{H}, \mathrm{m}\right.$ (with satellites)), $7.94\left(1 \mathrm{H}, \mathrm{d},{ }^{3} J_{\mathrm{HH}}=8.0 \mathrm{~Hz}\right), 7.75(1 \mathrm{H}, \mathrm{s}), 7.71-7.47(1 \mathrm{H}, \mathrm{m}), 7.58-7.56$ $(1 \mathrm{H}, \mathrm{m}), 7.51-7.47(1 \mathrm{H}, \mathrm{d}), 7.21-7.19(2 \mathrm{H}, \mathrm{m}), 6.51\left(1 \mathrm{H}, \mathrm{br} . \mathrm{t},{ }^{3} J_{\mathrm{HH}}=5.6 \mathrm{~Hz}\right), 3.60(6 \mathrm{H}, \mathrm{s}$ (with satellites), $3.55-3.50(2 \mathrm{H}, \mathrm{m}), 1.72-1.65(2 \mathrm{H}, \mathrm{m}), 1.43-1.25(10 \mathrm{H}, \mathrm{m}), 0.89\left(3 \mathrm{H}, \mathrm{t},{ }^{3} \mathrm{~J}_{\mathrm{HH}}=7.2 \mathrm{~Hz}\right)$ ppm. ${ }^{13} \mathrm{C}\left\{{ }^{1} \mathrm{H}\right\}$ NMR $\left(75.6 \mathrm{MHz}, \mathrm{CDCl}_{3}\right): \delta_{\mathrm{C}} 166.7,166.2,147.1,146.7,145.6,142.8,133.7,130.8$, $130.0,128.6,127.9,126.1,125.5,124.8,124.5,114.3,46.2,41.0,40.4,31.9,29.6,29.3,27.1,22.7$, 14.2 ppm. ${ }^{195} \mathrm{Pt}$ NMR $\left(107.51 \mathrm{MHz}, \mathrm{CDCl}_{3}\right): \delta_{\mathrm{Pt}}-2672 \mathrm{ppm} . \mathrm{MS}(\mathrm{ES})$ found $\mathrm{m} / \mathrm{z}=618.9$ for $[\mathrm{M}-$ $\mathrm{Cl}-\mathrm{DMSO}+2 \mathrm{MeOH}]^{+} . \mathrm{UV}$-vis $\left(\mathrm{CHCl}_{3}\right): \lambda_{\max }\left(\varepsilon / \mathrm{dm}^{3} \mathrm{~mol}^{-1} \mathrm{~cm}^{-1}\right) 272$ (18440), 281 (16980), 368 (4190), nm. IR (thin film): $v_{\max } 1647 \mathrm{~cm}^{-1}$.

Synthesis of $\left[\mathbf{P t}\left(\mathbf{L}^{2}\right)(\mathbf{D M S O}) \mathbf{C l}\right]$ : as for $\left[\mathbf{P t}\left(\mathbf{L}^{\mathbf{1}}\right)(\mathbf{D M S O}) \mathbf{C l}\right]$, but using $\left[\mathbf{P t}\left(\mathbf{L}^{2}\right)(\boldsymbol{\mu}-\mathbf{C l})\right]_{2}(0.068 \mathrm{~g}$, $0.026 \mathrm{mmol})$. Yield $=0.035 \mathrm{~g}(93 \%) .{ }^{1} \mathrm{H} \mathrm{NMR}\left(400 \mathrm{MHz}, \mathrm{CDCl}_{3}\right): \delta_{\mathrm{H}} 8.92\left(1 \mathrm{H}, \mathrm{d},{ }^{3} J_{\mathrm{HH}}=8.8 \mathrm{~Hz}\right)$, $8.28-8.25(1 \mathrm{H}, \mathrm{m}), 7.91\left(1 \mathrm{H}, \mathrm{d},{ }^{3} J_{\mathrm{HH}}=8.0 \mathrm{~Hz}\right), 7.70(1 \mathrm{H}, \mathrm{s}), 7.68-7.64(1 \mathrm{H}, \mathrm{m}), 7.55-7.53(1 \mathrm{H}$, m), $7.47-7.43(1 \mathrm{H}, \mathrm{m}), 7.19-7.17(2 \mathrm{H}, \mathrm{m}), 6.66\left(1 \mathrm{H}\right.$, br. $\left.\mathrm{t},{ }^{3} J_{\mathrm{HH}}=5.6 \mathrm{~Hz}\right), 3.59(6 \mathrm{H}$, s (with satellites)), $3.52-3.47(2 \mathrm{H}, \mathrm{m}), 1.71-1.64(2 \mathrm{H}, \mathrm{m}), 1.43-1.22(18 \mathrm{H}, \mathrm{m}), 0.87(3 \mathrm{H}, \mathrm{t}, 6.8 \mathrm{~Hz})$ ppm. ${ }^{13} \mathrm{C}\left\{{ }^{1} \mathrm{H}\right\}$ NMR $\left(75.6 \mathrm{MHz}, \mathrm{CDCl}_{3}\right): \delta_{\mathrm{C}} 207.1,166.6,166.1,147.0,146.6,145.6,142.5,129.9$, $128.5,127.8,126.1,125.4,124.8,114.2,53.5,46.2,41.0,40.3,31.0,29.7,29.6,29.6,29.4,29.3$, 14.2 ppm. ${ }^{195} \mathrm{Pt}$ NMR $\left(107.51 \mathrm{MHz}, \mathrm{CDCl}_{3}\right): \delta_{\mathrm{Pt}}-2681 \mathrm{ppm} . \mathrm{MS}(\mathrm{ES})$ found $\mathrm{m} / \mathrm{z}=683.3$ for $[\mathrm{M}-$ $\mathrm{DMSO}-\mathrm{Cl}+\mathrm{MeCN}+\mathrm{MeOH}]^{+} \cdot \mathrm{UV}$-vis $\left(\mathrm{CHCl}_{3}\right): \lambda_{\max }\left(\varepsilon / \mathrm{dm}^{3} \mathrm{~mol}^{-1} \mathrm{~cm}^{-1}\right) 281(20000), 363$ (5480) nm. IR (thin film): $v_{\max } 1645,1543 \mathrm{~cm}^{-1}$. 
Synthesis of $\left[\mathbf{P t}\left(\mathbf{L}^{3}\right)(\mathbf{D M S O}) \mathbf{C l}\right]$ : as for $\left[\mathbf{P t}\left(\mathbf{L}^{1}\right)(\mathbf{D M S O}) \mathbf{C l}\right]$, but using $\left[\mathbf{P t}\left(\mathbf{L}^{3}\right)(\mu-\mathbf{C l})\right]_{2}(0.095 \mathrm{~g}$, $0.068 \mathrm{mmol})$. Yield $=0.071 \mathrm{~g}(67 \%) .{ }^{1} \mathrm{H} \mathrm{NMR}\left(400 \mathrm{MHz}, \mathrm{CDCl}_{3}\right): \delta_{\mathrm{H}} 8.91\left(1 \mathrm{H}, \mathrm{d},{ }^{3} J_{\mathrm{HH}}=8.8 \mathrm{~Hz}\right)$, $8.27-8.25(1 \mathrm{H}, \mathrm{m}), 7.91\left(1 \mathrm{H}, \mathrm{d},{ }^{3} J_{\mathrm{HH}}=8.4 \mathrm{~Hz}\right), 7.71(1 \mathrm{H}, \mathrm{s}), 7.68-7.64(1 \mathrm{H}, \mathrm{m}), 7.55-7.53$ $(1 \mathrm{H}, \mathrm{m}), 7.47-7.43(1 \mathrm{H}, \mathrm{m}), 7.19-7.17(2 \mathrm{H}, \mathrm{m}), 6.90\left(1 \mathrm{H}\right.$, br. $\left.\mathrm{t},{ }^{3} J_{\mathrm{HH}}=6.0 \mathrm{~Hz}\right), 3.58(6 \mathrm{H}, \mathrm{s}$ (with satellites)), $3.51-3.46(2 \mathrm{H}, \mathrm{m}), 1.70-1.63(2 \mathrm{H}, \mathrm{m}), 1.42-1.18(26 \mathrm{H}, \mathrm{m}), 0.86\left(3 \mathrm{H}, \mathrm{t},{ }^{3} J_{\mathrm{HH}}=6.8\right.$ Hz) ppm. ${ }^{195} \mathrm{Pt}$ NMR $\left(107.51 \mathrm{MHz}, \mathrm{CDCl}_{3}\right): \delta_{\mathrm{Pt}}-2678 \mathrm{ppm}$. MS(ES) found $m / z=739.4$ for $[\mathrm{M}-$ $\mathrm{DMSO}-\mathrm{Cl}+\mathrm{MeCN}+\mathrm{MeOH}]^{+}$. HR MS found $m / z=813.2514 ; \mathrm{C}_{34} \mathrm{H}_{49} \mathrm{~N}_{2} \mathrm{SO}_{2} \mathrm{Cl}_{2}{ }^{194} \mathrm{Pt}[\mathrm{M}+\mathrm{Cl}]$ requires 813.2513. UV-vis $\left(\mathrm{CHCl}_{3}\right): \lambda_{\max }\left(\varepsilon / \mathrm{dm}^{3} \mathrm{~mol}^{-1} \mathrm{~cm}^{-1}\right) 265$ (10130), 284 (9640), 365 (4460) nm. IR (thin film): $v_{\max } 1639,1543 \mathrm{~cm}^{-1}$.

Synthesis of [Pt( $\left.\left.\mathbf{L}^{1}\right)(\mathbf{a c a c})\right]$ : $\left[\mathrm{Pt}\left(\mathbf{L}^{\mathbf{1}}\right)(\mathrm{DMSO}) \mathrm{Cl}\right](0.044 \mathrm{~g}, 0.066 \mathrm{mmol})$ and sodium acetylacetonate monohydrate $(0.080 \mathrm{~g}, 0.660 \mathrm{mmol})$ was dissolved in 3-pentanone $(5 \mathrm{~mL})$. The reaction was stirred at room temperature for $16 \mathrm{~h}$ under dinitrogen. The solvent was removed in vacuo and the crude product dissolved in dichloromethane $(10 \mathrm{~mL})$ and filtered to remove any insoluble salts. The crude product was purified by column chromatography (silica, dichloromethane) where elution of the first yellow band with dichloromethane gave the desired product obtained as a dark yellow solid. Yield $=0.038 \mathrm{~g}(89 \%) .{ }^{1} \mathrm{H} \mathrm{NMR}\left(400 \mathrm{MHz}, \mathrm{CDCl}_{3}\right): \delta_{\mathrm{H}} 9.43\left(1 \mathrm{H}, \mathrm{d},{ }^{3} J_{\mathrm{HH}}=8.8 \mathrm{~Hz}\right), 8.00\left(1 \mathrm{H}, \mathrm{dd},{ }^{3} J_{\mathrm{HH}}=\right.$ $\left.8.4 \mathrm{~Hz},{ }^{4} J_{\mathrm{HH}}=1.2 \mathrm{~Hz}\right), 7.70-7.64(2 \mathrm{H}, \mathrm{m}), 7.57(1 \mathrm{H}, \mathrm{s}), 7.51-7.47(1 \mathrm{H}, \mathrm{m}), 7.33\left(1 \mathrm{H}, \mathrm{dd},{ }^{3} J_{\mathrm{HH}}=\right.$ $\left.8.0 \mathrm{~Hz},{ }^{4} J_{\mathrm{HH}}=1.2 \mathrm{~Hz}\right), 7.17-7.13(1 \mathrm{H}, \mathrm{m}), 7.02-6.98(1 \mathrm{H}, \mathrm{m}), 6.66\left(1 \mathrm{H}, \mathrm{br} . \mathrm{t},{ }^{3} J_{\mathrm{HH}}=6.0 \mathrm{~Hz}\right)$, $5.57(1 \mathrm{H}, \mathrm{s}), 3.55-3.50(2 \mathrm{H}, \mathrm{m}), 2.04(3 \mathrm{H}, \mathrm{s}), 2.03(3 \mathrm{H}, \mathrm{s}), 1.75-1.67(2 \mathrm{H}, \mathrm{m}), 1.45-1.28(10 \mathrm{H}$, m), $0.91\left(3 \mathrm{H}, \mathrm{t},{ }^{3} J_{\mathrm{HH}}=6.8 \mathrm{~Hz}\right) \mathrm{ppm} .{ }^{13} \mathrm{C}\left\{{ }^{1} \mathrm{H}\right\} \mathrm{NMR}\left(75.6 \mathrm{MHz}, \mathrm{CDCl}_{3}\right): \delta_{\mathrm{C}} 185.7,184.0,169.3$, $166.8,149.4,145.7,144.7,139.8,131.0,129.7,129.6,127.1,126.5,125.2,125.1,124.5,124.0$, 114.2, 101.9, 40.3, 31.9, 29.8, 29.4, 28.5, 27.3, 27.2, 22.8, 14.2 ppm. ${ }^{195} \mathrm{Pt}$ NMR (107.51 MHz, $\left.\mathrm{CDCl}_{3}\right):-2776 \mathrm{ppm}$. MS(ES) found $\mathrm{m} / z=652.2$ for $[\mathrm{M}-\mathrm{H}]^{-}$. UV-vis $\left(\mathrm{CHCl}_{3}\right): \lambda_{\max }\left(\varepsilon / \mathrm{dm}^{3} \mathrm{~mol}^{-1}\right.$ $\left.\mathrm{cm}^{-1}\right) 300$ (9920), 349 (2810), 368 (3126), 423 (2420) nm. IR (thin film): $v_{\max } 1738,1643,1582 \mathrm{~cm}^{-}$ 1. 
Synthesis of $\left[\mathbf{P t}\left(\mathbf{L}^{2}\right)(\mathbf{a c a c})\right]$ : as $\left[\mathbf{P t}\left(\mathbf{L}^{1}\right)(\mathbf{a c a c})\right]$, but using $\left[\operatorname{Pt}\left(\mathbf{L}^{2}\right)(\mathrm{DMSO}) \mathrm{Cl}\right](0.035 \mathrm{~g}, 0.048 \mathrm{mmol})$ and sodium acetylacetonate monohydrate $(0.059 \mathrm{~g}, 0.484 \mathrm{mmol})$. Yield $=0.031 \mathrm{~g}(90 \%) .{ }^{1} \mathrm{H}$ NMR $\left(500 \mathrm{MHz}, \mathrm{CDCl}_{3}\right): \delta_{\mathrm{H}} 9.48\left(1 \mathrm{H}, \mathrm{d},{ }^{3} J_{\mathrm{HH}}=9.0 \mathrm{~Hz}\right), 8.03\left(1 \mathrm{H}, \mathrm{d},{ }^{3} J_{\mathrm{HH}}=8.0 \mathrm{~Hz}\right), 7.72-7.67(2 \mathrm{H}$, m), $7.63(1 \mathrm{H}, \mathrm{s}), 7.53-7.50(1 \mathrm{H}, \mathrm{m}), 7.40-7.38\left(1 \mathrm{H}, \mathrm{d},{ }^{3} J_{\mathrm{HH}}=7.5 \mathrm{~Hz}\right), 7.19-7.16(1 \mathrm{H}, \mathrm{m}), 7.05$ $-7.02(1 \mathrm{H}, \mathrm{m}), 6.48\left(1 \mathrm{H}\right.$, br. $\left.\mathrm{t},{ }^{3} \mathrm{~J}_{\mathrm{HH}}=6.0 \mathrm{~Hz}\right), 5.57(1 \mathrm{H}, \mathrm{s}), 3.56-3.52(2 \mathrm{H}, \mathrm{m}), 2.04(3 \mathrm{H}, \mathrm{s}), 2.03$ $(3 \mathrm{H}, \mathrm{s}), 1.73-1.67(2 \mathrm{H}, \mathrm{m}), 1.35-1.22(18 \mathrm{H}, \mathrm{m}), 0.83-0.89\left(3 \mathrm{H}, \mathrm{t},{ }^{3} \mathrm{~J}_{\mathrm{HH}}=7.5 \mathrm{~Hz}\right) \mathrm{ppm} .{ }^{13} \mathrm{C}\left\{{ }^{1} \mathrm{H}\right\}$ NMR (75.6 MHz, $\left.\mathrm{CDCl}_{3}\right): \delta_{\mathrm{C}} 185.7,184.1,169.5,166.8,149.5,145.7,144.7,139.9,131.1,129.8$, $129.6,127.2,126.6,125.2,125.1,124.5,124.0,114.2,101.9,40.4,32.0,29.7,29.4,28.5,27.3$, 27.2, 22.8, $14.2 \mathrm{ppm} .{ }^{195} \mathrm{Pt} \mathrm{NMR}\left(107.51 \mathrm{MHz}, \mathrm{CDCl}_{3}\right)$ : $-2779 \mathrm{ppm}$. MS(ES) found $\mathrm{m} / z=708.5$ for $[\mathrm{M}-\mathrm{H}]^{-}$. HR MS found $m / z=725.2841 ; \mathrm{C}_{33} \mathrm{H}_{43} \mathrm{~N}_{2} \mathrm{O}_{4}{ }^{194} \mathrm{Pt}[\mathrm{M}+\mathrm{OH}]$ requires 725.2844. UV-vis $\left(\mathrm{CHCl}_{3}\right): \lambda_{\max }\left(\varepsilon / \mathrm{dm}^{3} \mathrm{~mol}^{-1} \mathrm{~cm}^{-1}\right) 284$ (4180), 368 (2910) nm. IR (thin film): $v_{\max } 1668,1523 \mathrm{~cm}^{-1}$.

Synthesis of $\left[\mathbf{P t}\left(\mathbf{L}^{3}\right)(\mathbf{a c a c})\right]$ : as $\left[\mathbf{P t}\left(\mathbf{L}^{\mathbf{1}}\right)(\mathbf{a c a c})\right]$, but using $\left[\operatorname{Pt}\left(\mathbf{L}^{\mathbf{3}}\right)(\mathrm{DMSO}) \mathrm{Cl}\right](0.071 \mathrm{~g}, 0.091 \mathrm{mmol})$ and sodium acetylacetonate monohydrate $(0.111 \mathrm{~g}, 0.911 \mathrm{mmol})$. Yield $=0.034 \mathrm{~g}(49 \%) .{ }^{1} \mathrm{H}$ NMR $\left(400 \mathrm{MHz}, \mathrm{CDCl}_{3}\right): \delta_{\mathrm{H}} 9.53\left(1 \mathrm{H}, \mathrm{d},{ }^{3} J_{\mathrm{HH}}=8.8 \mathrm{~Hz}\right), 8.07\left(1 \mathrm{H}, \mathrm{d},{ }^{3} J_{\mathrm{HH}}=8.4 \mathrm{~Hz}\right), 7.77-7.70(3 \mathrm{H}$, m), $7.57-7.53(1 \mathrm{H}, \mathrm{m}), 7.47\left(1 \mathrm{H}, \mathrm{dd},{ }^{3} J_{\mathrm{HH}}=7.2 \mathrm{~Hz},{ }^{4} J_{\mathrm{HH}}=1.2 \mathrm{~Hz}\right), 7.24-7.20(1 \mathrm{H}, \mathrm{m}), 7.12-$ $7.08(1 \mathrm{H}, \mathrm{m}), 6.29\left(1 \mathrm{H}\right.$, br. t, $\left.{ }^{3} J_{\mathrm{HH}}=5.6 \mathrm{~Hz}\right), 5.58(1 \mathrm{H}, \mathrm{s}), 3.59-3.54(2 \mathrm{H}, \mathrm{m}), 2.05(3 \mathrm{H}, \mathrm{s}), 2.04$ $(3 \mathrm{H}, \mathrm{s}), 1.74-1.67(2 \mathrm{H}, \mathrm{m}), 1.46-1.24(26 \mathrm{H}, \mathrm{m}), 0.88\left(3 \mathrm{H}, \mathrm{t},{ }^{3} J_{\mathrm{HH}}=7.2 \mathrm{~Hz}\right) \mathrm{ppm} .{ }^{195} \mathrm{Pt} \mathrm{NMR}$ (107.51 MHz, $\left.\mathrm{CDCl}_{3}\right)$ : -2791 ppm. $\mathrm{MS}(\mathrm{ES})$ found $m / z=764.4$ for $[\mathrm{M}-\mathrm{H}]^{-}$. UV-vis $\left(\mathrm{CHCl}_{3}\right): \lambda_{\max }$ ( $\left.\varepsilon / \mathrm{dm}^{3} \mathrm{~mol}^{-1} \mathrm{~cm}^{-1}\right) 263$ (7950), 293 (7580), 348 (2410), 357 (2720), 421 (1560) nm. IR (thin film): $v_{\max } 1669,1548 \mathrm{~cm}^{-1}$.

Synthesis of $\left[\mathbf{P t}\left(\mathbf{L}^{\mathbf{1}}\right)(\mathbf{8 - Q})\right]$ : Based on a modified literature methodology, ${ }^{30}$ using [Pt(L1)(DMSO)Cl] (0.033 g, $0.049 \mathrm{mmol}), \mathrm{Na}_{2} \mathrm{CO}_{3}(0.010 \mathrm{~g}, 0.099 \mathrm{mmol})$ and 8-hydroxyquinoline $(0.008 \mathrm{~g}, 0.054 \mathrm{mmol})$. The red solution was concentrated in vacuo and diethyl ether $(5 \mathrm{~mL})$ was 
added. The precipitate was filtered, washed with diethyl ether $(2 \times 10 \mathrm{~mL})$ to remove excess 8 hydroxyquinoline, and methanol $(1 \times 5 \mathrm{~mL})$. The solid was dissolved in dichloromethane and dried in vacuo to afford a red solid. Yield $=0.026 \mathrm{~g},(76 \%) .{ }^{1} \mathrm{H}$ NMR $\left(400 \mathrm{MHz}, \mathrm{CDCl}_{3}\right): \delta_{\mathrm{H}} 9.64(1 \mathrm{H}, \mathrm{d}$, $\left.{ }^{3} J_{\mathrm{HH}}=8.4 \mathrm{~Hz}\right), 8.95(1 \mathrm{H}, \mathrm{m}), 8.32\left(1 \mathrm{H}, \mathrm{d},{ }^{3} J_{\mathrm{HH}}=8.4 \mathrm{~Hz}\right), 7.90\left(1 \mathrm{H}, \mathrm{d},{ }^{3} J_{\mathrm{HH}}=8.0 \mathrm{~Hz}\right), 7.75-7.71$ $(1 \mathrm{H}, \mathrm{m}), 7.57-7.52(2 \mathrm{H}, \mathrm{m}), 7.43-7.38(2 \mathrm{H}, \mathrm{m}), 7.30-7.25(2 \mathrm{H}, \mathrm{m}), 7.18-7.12(2 \mathrm{H}, \mathrm{m}), 7.07-$ $7.04(1 \mathrm{H}, \mathrm{m}), 6.97\left(\mathrm{H}, \mathrm{d},{ }^{3} J_{\mathrm{HH}}=7.6 \mathrm{~Hz}\right), 6.88-6.85(1 \mathrm{H}, \mathrm{m}), 3.58-3.48(2 \mathrm{H}, \mathrm{m}), 1.81-1.72(2 \mathrm{H}$, m), $1.49-1.25(10 \mathrm{H}, \mathrm{m}), 0.92\left(3 \mathrm{H}, \mathrm{t},{ }^{3} J_{\mathrm{HH}}=6.8 \mathrm{~Hz}\right) \mathrm{ppm} .{ }^{195} \mathrm{Pt} \mathrm{NMR}\left(107.51 \mathrm{MHz}, \mathrm{CDCl}_{3}\right): \delta_{\mathrm{Pt}}-$ 2998 ppm. MS(ES) found $m / z=753.3$ for $[\mathrm{M}+\mathrm{MeOH}+\mathrm{Na}]^{+} . \mathrm{UV}$-vis $\left(\mathrm{CHCl}_{3}\right): \lambda_{\max }\left(\varepsilon / \mathrm{dm}^{3} \mathrm{~mol}^{-1}\right.$ $\left.\mathrm{cm}^{-1}\right) 280$ (10230), 370 (2530), 505 (750) nm. IR (thin film): $v_{\max } 1645,1539 \mathrm{~cm}^{-1}$.

Synthesis of [Pt( $\left.\left.\mathbf{L}^{2}\right)(\mathbf{8}-\mathbf{Q})\right]$ : as [Pt(L1)(8-Q)], but using [Pt(L2)(DMSO)Cl] (0.052 g, $\left.0.072 \mathrm{mmol}\right)$, $\mathrm{Na}_{2} \mathrm{CO}_{3}(0.038 \mathrm{~g}, 0.360 \mathrm{mmol})$ and 8-hydroxyquinoline $(0.021 \mathrm{~g}, 0.145 \mathrm{mmol})$. Yield $=0.033 \mathrm{~g}$ (61\%). ${ }^{1} \mathrm{H}$ NMR $\left(400 \mathrm{MHz}, \mathrm{CDCl}_{3}\right): \delta_{\mathrm{H}} 9.61\left(1 \mathrm{H}, \mathrm{d},{ }^{3} J_{\mathrm{HH}}=8.4 \mathrm{~Hz}\right), 8.94-8.88(1 \mathrm{H}, \mathrm{m}$ with satellites), $8.31\left(1 \mathrm{H}, \mathrm{d},{ }^{3} J_{\mathrm{HH}}=8.0 \mathrm{~Hz}\right), 7.86\left(1 \mathrm{H}, \mathrm{d},{ }^{3} J_{\mathrm{HH}}=8.0 \mathrm{~Hz}\right), 7.71-7.67(1 \mathrm{H}, \mathrm{m}), 7.56-7.50$ (3H, m), $7.39-7.35(2 \mathrm{H}, \mathrm{m}), 7.27-7.24(1 \mathrm{H}, \mathrm{m}) 7.14-6.97(4 \mathrm{H}, \mathrm{m}), 6.82-6.79(1 \mathrm{H}, \mathrm{m}), 3.57$ $3.49(2 \mathrm{H}, \mathrm{m}), 1.81-1.75(2 \mathrm{H}, \mathrm{m}), 1.48-1.25(18 \mathrm{H}, \mathrm{m}), 0.89\left(3 \mathrm{H}, \mathrm{t},{ }^{3} J_{\mathrm{HH}}=6.8 \mathrm{~Hz}\right) \mathrm{ppm} .{ }^{195} \mathrm{Pt}$ NMR (107.51 MHz, $\left.\mathrm{CDCl}_{3}\right): \delta_{\mathrm{Pt}}-2972 \mathrm{ppm}$. MS(ES) found $\mathrm{m} / z=777.8$ for $[\mathrm{M}+\mathrm{Na}]^{+}$. UV-vis $\left(\mathrm{CHCl}_{3}\right): \lambda_{\max }\left(\varepsilon / \mathrm{dm}^{3} \mathrm{~mol}^{-1} \mathrm{~cm}^{-1}\right) 265$ (8640), 368 (2640), 506 (750) nm. IR (thin film): $v_{\max }$ 1646, $1539 \mathrm{~cm}^{-1}$.

Synthesis of $\left[\mathbf{P t}\left(\mathbf{L}^{\mathbf{3}}\right)(\mathbf{8}-\mathbf{Q})\right]$ : as $\left[\mathbf{P t}\left(\mathbf{L}^{\mathbf{1}}\right)(\mathbf{8}-\mathbf{Q})\right]$, but using $\left[\operatorname{Pt}\left(\mathbf{L}^{\mathbf{3}}\right)(\mathrm{DMSO}) \mathrm{Cl}\right](0.029 \mathrm{~g}, 0.037 \mathrm{mmol})$, $\mathrm{Na}_{2} \mathrm{CO}_{3}(0.020 \mathrm{~g}, 0.186 \mathrm{mmol})$ and 8-hydroxyquinoline $(0.011 \mathrm{~g}, 0.074 \mathrm{mmol})$. Yield $=0.021 \mathrm{~g}$ (68\%). ${ }^{1} \mathrm{H}$ NMR (400 MHz, $\left.\mathrm{CDCl}_{3}\right): \delta_{\mathrm{H}} 9.64\left(1 \mathrm{H}, \mathrm{d},{ }^{3} J_{\mathrm{HH}}=8.8 \mathrm{~Hz}\right), 8.93(1 \mathrm{H}, \mathrm{d}$ (with satellites), $\left.{ }^{3} J_{\mathrm{HH}}=3.2 \mathrm{~Hz}\right), 8.31\left(1 \mathrm{H}, \mathrm{d},{ }^{3} J_{\mathrm{HH}}=8.0 \mathrm{~Hz}\right), 7.88\left(1 \mathrm{H}, \mathrm{d},{ }^{3} J_{\mathrm{HH}}=8.0 \mathrm{~Hz}\right), 7.74-7.70(1 \mathrm{H}, \mathrm{m}), 7.56-$ $7.52(2 \mathrm{H}, \mathrm{m}), 7.41-7.36(3 \mathrm{H}, \mathrm{m}), 7.29-7.24(1 \mathrm{H}, \mathrm{m}) 7.14-7.13(2 \mathrm{H}, \mathrm{m}), 7.06-7.03(1 \mathrm{H}, \mathrm{m})$, $6.97\left(1 \mathrm{H}, \mathrm{d},{ }^{3} \mathrm{~J}_{\mathrm{HH}}=7.6 \mathrm{~Hz}\right), 6.85-6.82(1 \mathrm{H}, \mathrm{m}), 3.56-3.45(2 \mathrm{H}, \mathrm{m}), 1.80-1.71(2 \mathrm{H}, \mathrm{m}), 1.45-$ 
$1.19(26 \mathrm{H}, \mathrm{m}), 0.88\left(3 \mathrm{H}, \mathrm{t},{ }^{3} \mathrm{~J}_{\mathrm{HH}}=7.2 \mathrm{~Hz}\right) \mathrm{ppm} .{ }^{195} \mathrm{Pt} \mathrm{NMR}\left(107.51 \mathrm{MHz}, \mathrm{CDCl}_{3}\right): \delta_{\mathrm{Pt}}-2977 \mathrm{ppm}$. $\operatorname{MS}(\mathrm{ES})$ found $m / z=833.5$ for $[\mathrm{M}+\mathrm{Na}]^{+}$. UV-vis $\left(\mathrm{CHCl}_{3}\right): \lambda_{\max }\left(\varepsilon / \mathrm{dm}^{3} \mathrm{~mol}^{-1} \mathrm{~cm}^{-1}\right) 352(2750)$, 369 (2590), 438 (1080), 504 (1190) nm. IR (thin film): $v_{\max } 1670,1597 \mathrm{~cm}^{-1}$.

\section{Acknowledgements}

Dr James A. Platts is thanked for supporting TD-DFT calculations. We thank Cardiff University for financial support and the staff of the EPSRC UK National Mass Spectrometry Facility at Swansea University. We also thank the EPSRC for the use of the National Crystallographic Service at the University of Southampton.

\section{References}

${ }^{1}$ a) J.A.G. Williams, S. Develay, D.L. Rochester, L. Murphy, Coord. Chem. Rev. 252 (2008) 2596;

b) A. Diez, E. Lalinde, M. Teresa Moreno, Coord. Chem. Rev. 255 (2011) 2426; c) A.M.

Prokhorov, T. Hofbeck, R. Czerwieniec, A.F. Suleymanova, D.N. Kozhevnikov, H. Yersin, J. Am. Chem. Soc. 136 (2014) 9637.

2 a) V.H. Houlding, A. J. Frank, Inorg. Chem. 24 (1985) 3664; b) T. Maruyama, T. Yamamoto, J. Phys. Chem. B 101 (1997) 3806.

${ }^{3}$ a) V. Anbalagan, T.S. Srivastava, J. Photochem. Photobiol. A: Chem. 89 (1995) 113; b) Nolan, D.; Gil, B.; Wang, L.; Zhao, J.; Draper, S. M. Chem. Eur. J. 19 (2013) 15615; c) O. J. Stacey, S. J. A. Pope, RSC Adv. 3 (2013) 25550; d) S. W. Lai, Y. Liu, D. Zhang, B. Wang, C.N. Lok, C.M. Che, M. Selke, Photochem. Photobiol. 86 (2010) 1414-1420.

${ }^{4}$ a) M.A. Baldo, D.F. O’Brien, Y. You, A. Shoustikov, S. Sibley, M.E. Thompson, S.R. Forrest, Nature 395 (1998) 151; b) R. C. Kwong, S. Sibley, T. Dubovoy, M.A. Baldo, S.R. Forrest, M.E. Thompson, Chem. Mater. 11 (1999) 3709; c) D.F. O’Brien, M.A. Baldo, M.E. Thompson, S.R. Forrest, Appl. Phys. Lett. 74 (1999) 442 
${ }^{5}$ a) M. Mauro, A. Aliprandi, D. Septiadi, N.S. Kehr, L. De Cola, Chem. Soc. Rev. 43 (2014) 41444166; b) E. Baggaley, J.A. Weistein, J.A.G. Williams, Coord. Chem. Rev. 256 (2012) 1762-1785; S.W. Botchway, M. Charnley, J.W. Haycock, A.W. Parker, D.L. Rochester, J.A. Weinstein, J.A.G. Williams, Proc. Natl. Acad. Sci. U.S.A. 105 (2008) 16071-16076

${ }^{6}$ a) T-S. Yeh, C-S. Chu, Y-L. Lo, Sensors Act. B 119 (2006) 701-707; b) H. Guo, S. Ji, W. Wu, J. Shao, J. Zhao, Analyst 135 (2010) 2832-2840; c) W. Wu, S. Ji, W. Wu, J. Zhao, H. Guo Dalton Trans. 40 (2011) 11550-11561; d) L.J. Grove, J.M. Rennekamp, H. Jude, W.B. Connick, J. Am. Chem. Soc. 126 (2004) 1594-1595; e) X. Zhang, J-Y. Wang, J. Ni, L-Y. Zhang, Z-N. Chen, Inorg, Chem. 51 (2012) 5569-5579; f) J. Ni, Y-G. Wang, J-Y. Wang, Y-Q. Zhao, Y-Z. Pan, H-H. Wang, X. Zhang, J-J. Zhang, Z-N. Chen, Dalton Trans. 42 (2013) 13092-13100; g) A. Kobayashi, K. Masako, Eur. J. Inorg. Chem. 2014 4469-4483.

7 a) D. Valensin, C. Gabbiani, L. Messori, Coord. Chem. Rev. 256 (2012) 2357-2366; b) K.J. Barnham, V.B. Kenche, G.D. Ciccotosto, D.P. Smith, D.J. Tew, X. Liu, K. Perez, G.A. Cranston, T.J. Johanssen, I. Volitakis, A.I. Bush, C.L. Masters, A.R. White, J.P. Smith, R.A. Cherny, R. Cappai, Proc. Natl. Acad. Sci. U.S.A. 105 (2008) 6813; b) F. Collin, I. Sasaki, H. Eury, P. Faller, C. Hureau, Chem. Commun. 49 (2013) 2130.

${ }^{8}$ a) B. Rosenberg, L. Van Camp, J.E. Trosko, V.H. Mansour, Nature 222 (1969) 385; b) B.J. Pages, D.L. Ang, E.P. Wright, J.R. Adrich-Wright, Dalton Trans. 44 (2015) 3505; c) C.S. Peyratout, T.K. Aldridge, D.K. Crites, D.R. McMillin, Inorg. Chem. 44 (1995) 4484; d) A.H.-J. Wang, J. Nathans, G.A. van der Marel, J.H. van Boom, A. Rich, Nature 276 (1978) 471.

${ }^{9}$ J. Holford, F. Raynaud, B.A. Murrer, K. Grimaldi, J.A. Hartley, M. Abrams, L.R. Kelland, AntiCancer Drug Design 13 (1998) 1.

${ }^{10}$ a) N.S. Bryce, J.Z. Zhang, R.M. Whan, N. Yamamoto, T.W. Hambley, Chem. Commun. (2009) 2673; b) J.Z. Zhang, N.S. Bryce, A. Lanzirotti, C.K.J. Chen, D. Paterson, M.D. de Jonge, D.L. Howard, T.W. Hambley, Metallomics 4 (2012) 1209; c) R.M. Whan, B.A. Messerle, T.W. 
Hambley, Dalton Trans. (2009) 932; d) R.A. Alderden, H.R. Mellor, S. Modok, T.W. Hambley, R. Callaghan, Biochem. Pharmocol. 71 (2006) 1136.

${ }^{11}$ O.J. Stacey, J.A. Platts, S.J. Coles, P.N. Horton, S.J.A. Pope, Inorg. Chem. 54 (2015) 6528

${ }^{12}$ O.J. Stacey, A.J. Amoroso, J.A. Platts, P.N. Horton, S.J. Coles, D. Lloyd, A.J. Hayes, J.J.

Dunsford, S.J.A. Pope, Chem. Commun. 51 (2015) 12305.

${ }^{13}$ For example, B.J. Pages, Y. Zhang, F. Li, J. Sakoff, J. Gilbert, J.R. Aldrich-Wright, Eur. J. Inorg. Chem. (2015) 4167; C.R. Brodie, J.G. Collins, J.R. Aldrich-Wright, Dalton Trans. (2004) 1145.

14 a) J.D. Routledge, A.J. Hallett, J.A. Platts, P.N. Horton, S.J. Coles, S.J.A. Pope, Eur. J. Inorg. Chem. 25 (2012) 4065; b) R.A. Smith, E.C. Stokes, E.E. Langdon-Jones, J.A. Platts, B.M. Kariuki, A.J. Hallett, S.J.A. Pope, Dalton Trans. 42 (2013) 10347.

15 a) A.J. Amoroso, M.P. Coogan, J.E. Dunne, V. Fernandez-Moreira, J.B. Hess, A.J. Hayes, D. Lloyd, C. Millet, S.J.A. Pope, C. Williams, Chem. Commun. (2007) 3066; b) M.P. Coogan, V. Fernandez-Moreira, J.B. Hess, S.J.A. Pope, C. Williams, New J. Chem. 33 (2009) 1094; c) R.G. Balasingham, F.L. Thorp-Greenwood, C.F. Williams, M.P. Coogan, S.J.A. Pope, Inorg. Chem. 51 (2012) 1419; d) A.J. Amoroso, R.J. Miller, M.P. Coogan, J.B. Court, V. Fernandez-Moreira, A.J. Hayes, D. Lloyd, C. Millet, S.J.A. Pope, New J. Chem. 32 (2008) 1097; e) F.L. Thorp-Greenwood, M.P. Coogan, A.J. Hallett, R.H. Laye, S.J.A. Pope, J. Organomet. Chem. 694 (2009) 1400; f) R.O. Bonello, I.R. Morgan, B.R. Yeo, L.E.J. Jones, B.M. Kariuki, I.A. Fallis, S.J.A. Pope, J. Organomet. Chem. 749 (2014) 150.

16 a) C. Cutrin Prieto, E. Nieto Pol, A. Batalla Eiras, L. Casal Iglesias, E. Perez Becerra and V. Lorenzo Zuniga, Med. Clin. 97 (1991) 104; b) W.J. Geldenhuys, S. R. Kuzenko and M. A.

Simmons, J. Med. Chem. 53 (2010) 8080; c) F. E. Blaney, L. F. Raveglia, M. Artico, S. Cavagnera, C. Dartois, C. Farina, M. Grugni, S. Gagliardi, M. A. Luttmann, M. Martinelli, G.M.M.G. Nadler, C. Parini, P. Petrillo, H. M. Sarau, M.A. Scheideler, D.W.P. Hay and G.A.M. Giardina, J. Med. Chem. 44 (2001) 1675; d) G.A.M. Giardina, L.F. Raveglia, M. Grugni, H.M. Sarau, C. Farina, A. 
D. Medhurst, D. Graziani, D. B. Schmidt, R. Rigolio, M. Luttmann, S. Cavagnera, J. J. Foley, V. Vecchietti and D. W. P. Hay, J. Med. Chem. 42 (1999) 1053.

${ }^{17}$ B.M. Still, P.G.A. Kumar, J.R. Aldrich-Wright, W.S. Price, Chem. Soc. Rev. 36 (2007) 665.

${ }^{18}$ S. Alvarez, Dalton Trans. 42 (2013) 8617.

${ }^{19}$ W. Goodall, J.A.G. Williams, J. Chem. Soc., Dalton Trans. (2000) 2893; C.J. Adams, S.J.A. Pope, Inorg. Chem. 43 (2004) 3492.

${ }^{20}$ M. Frank, M. Nieger, F. Vogtle, P. Belser, A. von Zelewsky, L. de Cola, V. Balzani, F. Barigelletti, L. Flamigni, Inorg. Chim. Acta 242 (1996) 281.

${ }^{21}$ S.J. Coles, P.A. Gale, Chem. Sci. 3 (2012) 683.

${ }^{22}$ Rigaku, CrystalClear- SM Expert 3.1 b27 (2013).

${ }^{23}$ Shedrick, G.M. Acta Cryst. C71 (2015) 3-8.

${ }^{24}$ M.J. Frisch, G.W. Trucks, H.B. Schlegel, G.E. Scuseria, M.A. Robb, J.R. Cheeseman, J.A. Montgomery Jr., T. Vreven, K.N. Kudin, J.C. Burant, J.M. Millam, S.S. Iyengar, J. Tomasi, V. Barone, B. Mennucci, M. Cossi, G. Scalmani, N. Rega, G.A. Petersson, H. Nakatsuji, M. Hada, M. Ehara, K. Toyota, R. Fukuda, J. Hasegawa, M. Ishida, T. Nakajima, Y. Honda, O. Kitao, H. Nakai, M. Klene, X. Li, J.E. Knox, H.P. Hratchian, J.B. Cross, V. Bakken, C. Adamo, J. Jaramillo, R. Gomperts, R.E. Stratmann, O. Yazyev, A.J. Austin, R. Cammi, C. Pomelli, J.W. Ochterski, P.Y. Ayala, K. Morokuma, G.A. Voth, P. Salvador, J.J. Dannenberg, V.G. Zakrzewski, S. Dapprich, A.D. Daniels, M.C. Strain, O. Farkas, D.K. Malick, A.D. Rabuck, K. Raghavachari, J.B. Foresman, J.V. Ortiz, Q. Cui, A.G. Baboul, S. Clifford, J. Cioslowski, B.B. Stefanov, G. Liu, A. Liashenko, P. Piskorz, I. Komaromi, R.L. Martin, D.J. Fox, T. Keith, M.A. Al-Laham, C.Y. Peng, A. Nanayakkara, M. Challacombe, P.M.W. Gill, B. Johnson, W. Chen, M.W. Wong, C. Gonzalez, J.A. Pople, Gaussian 03, Revision E.01. Gaussian, Inc., Wallingford CT, 2004. 
25 a) A.D. Becke, J. Chem. Phys. 98 (1993) 5648-5652; b) C. Lee, W. Yang, R.G. Parr, Phys. Rev. B 37 (1988) 785 .

${ }^{26}$ D. Andrae, U. Haeussermann, M. Dolg, H. Stoll, H. Preuss, Theor. Chem. Acc. 77 (1990) 123.

27 a) R. Ditchfield, W.J. Hehre, J.A. Pople, J. Chem. Phys. 54 (1971) 724; b) W.J. Hehre, R.

Ditchfield, J.A. Pople, J. Chem. Phys. 56 (1972) 2257; c) P.C. Hariharan, J.A. Pople, Theor. Chem. Acc. 28 (1973) 213.

${ }^{28}$ J. Tomasi, B. Mennucci, R. Cammi, Chem. Rev. 105 (2005) 2999.

${ }^{29}$ D.S. Black, G.B. Deacon, G.L. Edwards, Aust. J. Chem. 47 (1994) 217.

${ }^{30}$ N.M. Shavaleev, H. Adams, J. Best, R. Edge, S. Navaratnam, J.A. Weinstein, Inorg. Chem. 45 (2006) 9410 . 